\title{
EXPERIMENTAL INVESTIGATIONS ON CANTILEVER FAILURES FOR COHESIVE RIVERBANKS
}

\author{
Supapap PATSINGHASANEE ${ }^{1}$, Ichiro KIMURA ${ }^{2}$, Yasuyuki SHIMIZU³ ${ }^{3}$ \\ Takamasa TODATE 4 \\ ${ }^{1}$ Member of JSCE, Ph.D. candidate, Division of Field Engineering for Environment, Hokkaido University \\ (Kita 13, Nishi 8, Kitu-ku, Sapporo 060-8628, Japan) \\ ${ }^{2}$ Member of JSCE, Associate Prof., Division of Field Engineering for Environment, Hokkaido University \\ (Kita 13, Nishi 8, Kitu-ku, Sapporo 060-8628, Japan) \\ ${ }^{3}$ Member of JSCE, Professor, Division of Field Engineering for Environment, Hokkaido University \\ (Kita 13, Nishi 8, Kitu-ku, Sapporo 060-8628, Japan) \\ ${ }^{4}$ Undergraduate student, Division of Field Engineering for Environment, Hokkaido University \\ (Kita 13, Nishi 8, Kitu-ku, Sapporo 060-8628, Japan)
}

\begin{abstract}
This paper presents an experimental study of coupling fluvial erosion and cantilever failure with the slump block effect for cohesive banks. Two types of cohesive materials with different percentages of silt-clay content were investigated under similar hydraulic conditions using acceleration sensors to clarify failure phenomena. The experimental results showed that fluvial erosion of the lower part of the cohesive banks progressively undermines the upper part during the initial stage of a cantilever failure. Tension cracks then develop at the upper surface of the cohesive banks, and beam-type failure occurs thereafter. Furthermore, slump block failures and decompositions were observed as the new phenomena in this study. The geometries of slump block including its failure and decomposition mainly depended on the cohesive force of the cohesive banks. Therefore, a reduction of the silt-clay content leads to smaller slump block dimensions as well as faster decomposition.
\end{abstract}

Key Words : fluvial erosion, cantilever failure, slump block, cohesive riverbank, experiment

\section{INTRODUCTION}

Riverbank failure results in extensive sediment production in an alluvial channel, and can cause severe environmental and economic problems such as loss of fertilization in agriculture areas and destruction of infrastructure ${ }^{1)}$. However, because cantilever failure involves rapid channel widening and delivers a large volume of sediment into the channel, such a failure is a serious issue in river engineering ${ }^{2)}$. Elucidating the underlying mechanism of cantilever failure is therefore important for a full understanding of fluvial erosion and bank failure with the effect of slump blocks along a channel.

Only a few studies have applied stability analysis based on the safety factor of the portion with cantilever failure, from which three types of possible cantilever failure mechanisms - shear-type, beam-type and tensile-type failures - have been defined ${ }^{3,4)}$. However, the tensile-type failure was rarely observed along the actual rivers ${ }^{2), 3)}$.

For experimental studies, several small-scale experiments were carried out to examine fluvial erosion and cantilever failure phenomena ${ }^{5)}$ and to measure flow characteristics ${ }^{6}$. Moreover, a couple of large-scale experiments were conducted to estimate the failure plane angle and tension $\mathrm{crack}^{1)}$, and to investigate the dominant cantilever failure mechanism by using sandy gravel banks ${ }^{2)}$ and cohesive banks ${ }^{7)}$. However, all of the large-scale experiments focused solely on processes related to cantilever failure and the interaction between stagnant water and cohesive materials; fluvial erosion was not taken into account. Recently, the 
interaction between fluvial erosion and cantilever failure was investigated in a small-scale experimental flume ${ }^{8)}$.

After a cantilever failure, the overhanging blocks crumble down in a shape like slump blocks and cover the bank-toe. It is thought the fluvial erosion rate decreases because of the failure of slump blocks ${ }^{9}$. Moreover, the simplified process of slump blocks was expressed in small-scale experiments ${ }^{10)}$ and actual rivers ${ }^{11)}$ for the first time.

To address the gaps in the experimental study of the processes for a cantilever failure with slump block considerations, large-scale experiments were conducted on a straight rectangular flume to understand the complex mechanism of cantilever failure using high-resolution video cameras to measure the temporal bank width and acceleration sensors to clarify the failure mechanism inside the bank. Additionally, the slump block mechanisms during the progress of cantilever failure and its decomposition phenomena are discussed in laboratory experiments.

\section{METHODOLOGY}

The experiments related to fluvial erosion and cantilever failure were conducted using a fix bed in a straight rectangular flume with a Plexiglass wall to allow for real-time observation and recording. The water and sediments were recirculated using a constant-head tank of water placed at the upstream end of flume. Moreover, to reproduce a steady uniform flow, the water discharge was maintained constant at $6.45 \mathrm{l} / \mathrm{s}$. The initial water level was set to zero, and a free-flowing condition was controlled at the downstream end.

Generally, the main limitations of the previous experiments were the scale and sidewall correction effects. For this study, the geometrical and material scaling, and the sidewall correction effect were considered to form the cohesive banks and construct the experimental flume. Therefore, we employed a governing equation with regard to the shear-type failure of an overhanging block as follows ${ }^{7}$ :

$$
F_{s s}=f\left(C / \gamma_{s} b_{c}, h_{c} / b_{c}\right)
$$

where $F_{s s}$ is the factor of safety of shear-type failure, $C$ is the cohesive force $(\mathrm{Pa}), \gamma_{s}$ is the unit weight of soil $\left(\mathrm{N} / \mathrm{m}^{3}\right), b_{c}$ is the overhanging block width $(\mathrm{m})$, and $h_{c}$ is the overhanging block height (m).

Based on Eq.(1), if an overhanging block is formed in the laboratory, the values of the two dimensionless parameters must be similar in both the prototype and experimental model. Moreover, the overhanging block height affects both the resistant and driving forces acting on unit width of an overhanging failure block ${ }^{7)}$. Therefore, this parameter can be neglected in the stability analysis as shown in Eq.(2). Thus, it is only necessary to evaluate the remaining three parameters (i.e., cohesive force, unit weight, and block width) to model a cantilever failure in the laboratory:

$$
F_{s s}=C / \gamma_{s} b_{c}
$$

Based on the above explanation, $F_{s s}$ was assumed to be one, which is the critical point of an overhanging block. Moreover, $\gamma_{s}$ and $C$ of the materials were determined using a direct shear test ${ }^{8}$. After that, the block width can be estimated by substituting $F_{s s}, \gamma_{s}$, and $C$ into Eq.(2). As a result, the critical block width is equal to $0.23 \mathrm{~m}$. For the experimental design, the flume dimensions were 0.8 $\mathrm{m}$ in width, $8.0 \mathrm{~m}$ in length, and $0.4 \mathrm{~m}$ in height and the channel slope was set to 0.001 , as shown in Fig. 1. In the upstream region of the flume $(0.0-3.0 \mathrm{~m}$ from the upstream), a wooden board was installed to avoid fluvial erosion (I to II). At the middle reach of the flume (3.0-5.0 $\mathrm{m}$ from the upstream), a cohesive bank was set (II to III). The cohesive bank was 0.5 $\mathrm{m}$ wide, which was about two times larger than the estimated value $(0.23 \mathrm{~m}), 2.0 \mathrm{~m}$ long, and $0.2 \mathrm{~m}$ high. Downstream of the cohesive bank, a second wooden board was installed to protect the cohesive bank from fluvial erosion (III to IV).

For sediment preparations, the significant parameter in cantilever failure is the cohesive force. The cohesive force is mainly related to the silt-clay content $^{8), 10)}$ and water content ${ }^{8), 12)}$. Therefore, sediment mixture in this experimental studies composed of sand and silt with a mean diameter $\left(d_{50}\right)$ of around $0.23 \mathrm{~mm}$ and $28.4 \mu \mathrm{m}$, respectively, was used. The sediment was well mixed and massaged by slowly adding water. The sediment mixture was thus initially wetted with water to achieve a water content between $32.2 \%$ and $39.6 \%$ for the silt-clay content (SC) of $20 \%$ and $30 \%$. To allow a sufficient consolidation process, the cohesive banks were compacted by applying a static load of $0.04 \mathrm{~kg} / \mathrm{cm}^{2}$ for $72 \mathrm{~h}^{2), 8)}$. During the bank construction, a wooden panel was positioned to form a vertical bank. This panel was removed before the experiment started. The silt-clay content, water content, cohesive force, and the friction angle used during the experiments are summarized in Table 1.

Table 1 Summary of the experimental conditions.

\begin{tabular}{|c|c|c|c|c|}
\hline Case & $\begin{array}{c}\text { Silt-Clay } \\
\text { content } \\
(\%)\end{array}$ & $\begin{array}{c}\text { Water } \\
\text { content } \\
(\%)\end{array}$ & $\begin{array}{c}\text { Cohesive } \\
\text { force } \\
(\mathrm{kPa})\end{array}$ & $\begin{array}{c}\text { Friction } \\
\text { angle } \\
(\text { degree })\end{array}$ \\
\hline 1 & 30 & 39.6 & 5.76 & 34.3 \\
\hline 2 & 20 & 32.2 & 6.41 & 41.3 \\
\hline
\end{tabular}




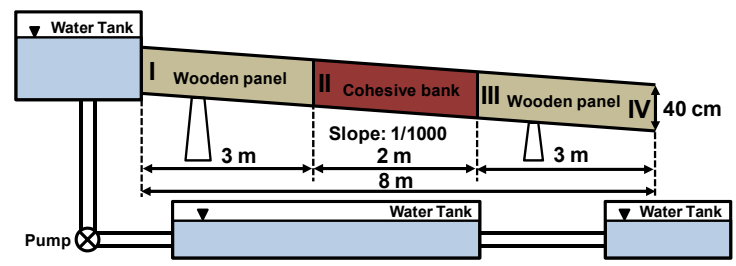

(a) Overview of experimental setup.

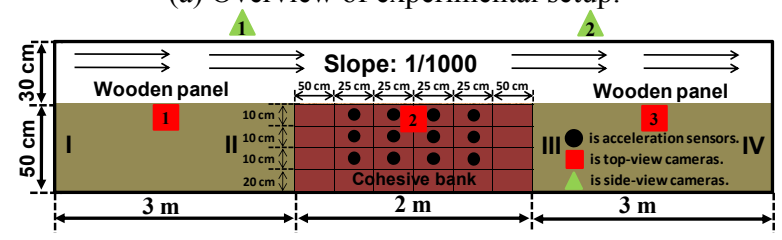

(b) Top-view of experimental channel.

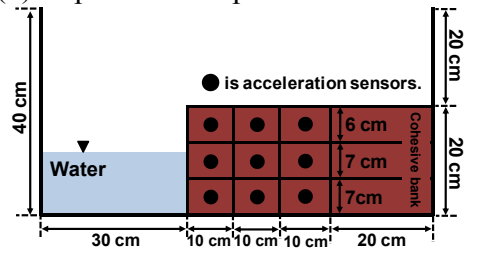

(c) Cross-section of experimental channel.

Fig.1 The dimensions of experimental channel.

The advantage of the experiment was the possibility to observe and record the cantilever failure mechanism from the top and side views, and inside the cohesive bank of the experimental flume. All failure mechanisms were recorded using 5 high-resolution video cameras and 36 acceleration sensors, as shown in Fig. 1(b) and 1(c). The video cameras were positioned at a fixed perpendicular position for the top and side views of the flume to record the temporal bank width and water depth. Additionally, the metric scales were positioned in both horizontal and vertical directions of the flume. The video frames were subsequently converted into gray-scale metrics, and the temporal bank width and water depth were determined through a digitization process with a precision of around $1 \mathrm{~mm}$. The acceleration sensors were installed inside the bank. Acceleration signals in the $x-y-z$ directions would be produced by the failure and outflow of the installation positions. These sensors were of the self-recording type, and they must be collected after the completion of the experiment for data acquisition.

\section{RESULTS}

A summary of the cantilever failure and slump block effect during each experiment is provided with reference to the images of the temporal bank width and with the acceleration signals to clarify the failure mechanisms inside the cohesive bank.

We carried out a series of small-scale experiments to test the responses, in terms of fluvial erosion, tension crack, and cantilever failure, of the different silt-clay contents and water contents. For instance, we tested the possible silt-clay content and water content that appeared to be appropriate to reproduce the cantilever failure mechanisms. A summary of the initial tests was reported in a previous study ${ }^{8)}$. The results of these experiments were used to compare with and analyze the failure mechanisms in the large-scale experiments.

For large-scale experiments, an important task is to clarify the cantilever failure processes in chronological order. Therefore, the acceleration sensors were installed inside the cohesive banks. These sensors recorded the chronological failure mechanisms and identified the fluvial erosion or cantilever failure at points where the values varied greatly. As results of the acceleration values, Fig. 2 shows the acceleration values in the $x-y-z$ directions recorded by the sensors. For data interpretation, if the acceleration values suddenly change in the $y$-direction or $z$-direction, they mean that the beam-type or shear-type failure occurs in a cohesive bank, respectively. Moreover, the changed acceleration values in the $x$-direction mean that the fluvial force erodes a bank at the submerged zone. A summary of the failure processes determined in the experimental studies is as follows, with a reference photo reported in Fig. 3 and the temporal bank geometry measured using the acceleration sensors as shown in Fig. 4. For Fig. 4, a representative block of a sensor was removed from an initial cohesive bank, if the acceleration signals varied greatly.

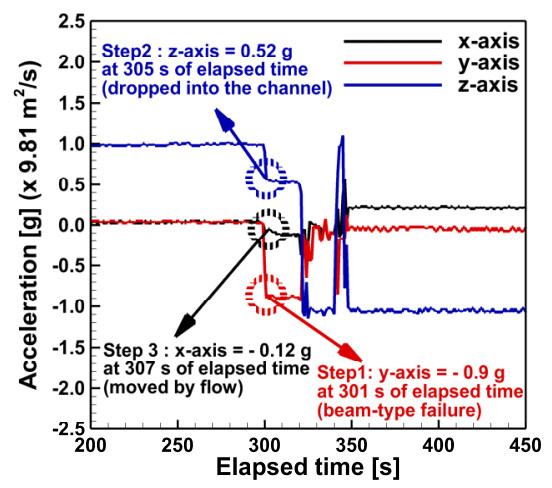

(a) Signal of beam-type failure mechanism.

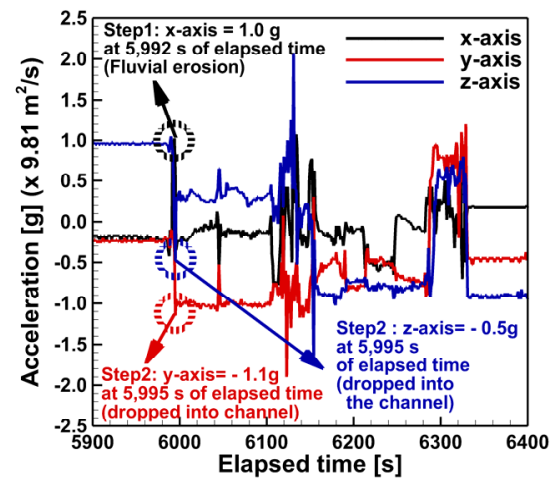

(b) Signal of fluvial erosion at the bank-toe.

Fig.2 Example results of data interpretations in Case 1. 
In Case 1, fluvial erosion occurred immediately after the experiment started. The first considerable tension crack and beam-type failure were observed from 7.4 to $134.7 \mathrm{~cm}$ from the upstream end at $296 \mathrm{~s}$ and at $300 \mathrm{~s}$, respectively. Moreover, the failure block dimensions were $12.9 \mathrm{~cm}$ in width and 127.3 $\mathrm{cm}$ in length. For the first failure, the decomposition time, which is time of decay processes of the slump block on the bed channel, was 163 s. After beam-type failure, the bank slope reshaped toward an angle of $90^{\circ}$. A large tension crack and beam-type failure were then observed at the downstream end from 119.9 to $200.0 \mathrm{~cm}$ at $461 \mathrm{~s}$. The slump block dimensions of this failure were $14.3 \mathrm{~cm}$ in width and $80.0 \mathrm{~cm}$ in length. Additionally, the decomposition time was $55 \mathrm{~s}$. From $1,560 \mathrm{~s}$ to $9,420 \mathrm{~s}$, six successive tension cracks and beam-type failures randomly developed along the cohesive bank. In addition, the decomposition time of the six successive failure blocks was within the range of $1,763 \mathrm{~s}$ to $3,917 \mathrm{~s}$. Furthermore, the average water levels along the channel fluctuated between $5.0 \mathrm{~cm}$ and $5.5 \mathrm{~cm}$ during the experiment. Finally, the experiment reached the equilibrium stage at 9,420 s.

In Case 2, during the initial stage, fluvial erosion occurred along the cohesive bank but was more evident in the downstream region from the started time to $1,890 \mathrm{~s}$. In the first and second cantilever failures, the experiment showed a backward erosion process from $144.1 \mathrm{~cm}$ to $191.8 \mathrm{~cm}$ (at $1,890 \mathrm{~s}$ ) and from $181.6 \mathrm{~cm}$ to $200.0 \mathrm{~cm}$ (at $3,120 \mathrm{~s}$ ) from the upstream end. The third and fourth beam-type failures were then developed at the middle region of the cohesive bank from $33.3 \mathrm{~cm}$ to $138.3 \mathrm{~cm}$ from the upstream end at $3,510 \mathrm{~s}$ and at $3,880 \mathrm{~s}$. The fourth tension crack is illustrated in Fig. 3(a), and the fourth beam-type failure is shown in Fig. 3(b) using the video cameras and in Fig. 4(c) using the acceleration sensors. Tension cracks and beam-type failure were then observed in rapid succession at the downstream end again at 4,770 s and at 5,100 s from $122.8 \mathrm{~cm}$ to $168.8 \mathrm{~cm}$ and from 157.9 to $200.0 \mathrm{~cm}$, respectively. Additionally, the last two beam-type failures developed at the upstream end at $5,505 \mathrm{~s}$ and at $6,600 \mathrm{~s}$. For the failure block dimensions, the width and length of failure blocks were within the range of $5.7 \mathrm{~cm}$ to $13.5 \mathrm{~cm}$ and of $17.6 \mathrm{~cm}$ to 47.7 $\mathrm{cm}$, respectively. The decomposition time for eight beam-type failures varied from $61 \mathrm{~s}$ to $904 \mathrm{~s}$. Moreover, the average water level along the channel was in the range of $5.0 \mathrm{~cm}$ to $6.8 \mathrm{~cm}$. Schematic diagrams of the temporal bank width of Case 2 are illustrated in Fig. 3(c). Finally, the experiment reached the equilibrium stage at 6,600 s (see Fig. 4(d)).

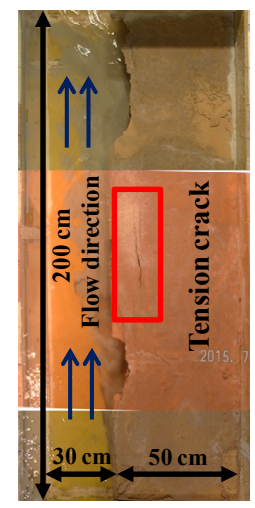

(a) Tension crack.

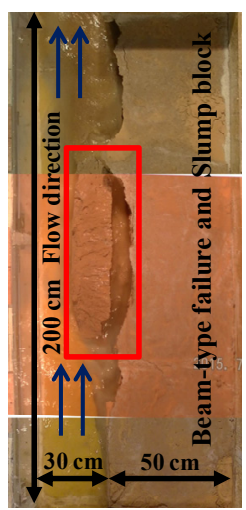

(b) Beam-type failure and Slump block.

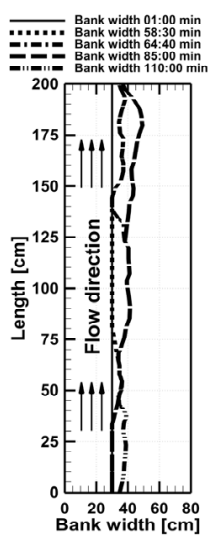

(c) Schematic diagram.
Fig.3 Example results of Case $2(S C=20 \%)$.

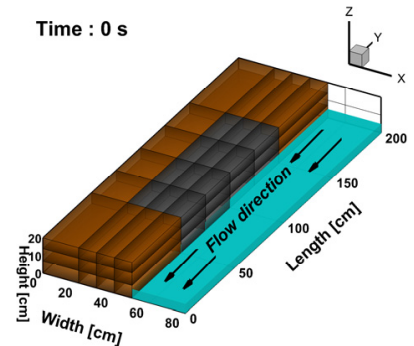

(a) Initial stage.

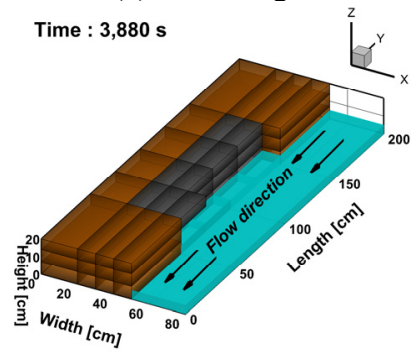

(c) Beam-type failure stage.

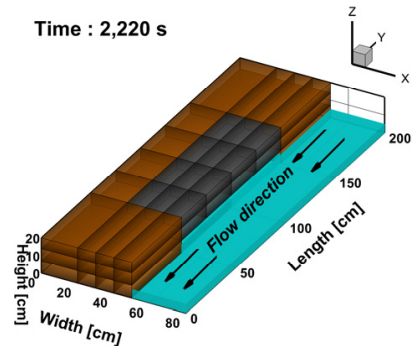

(b) Fluvial erosion stage.

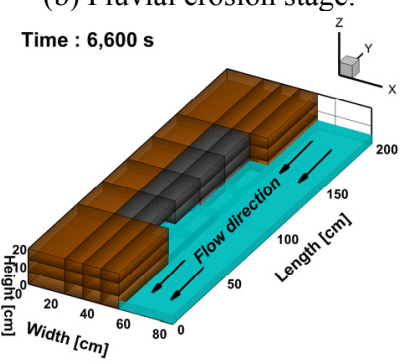

(d) Equilibrium stage.
Fig.4 Example results of Case $2(S C=20 \%)$ using the acceleration sensors.

\section{DISCUSSION}

For the flow conditions, the Reynolds numbers were within the range of 15,000 to 40,000 and the Froude numbers were lower than 1, which corresponded to a turbulent flow and a subcritical flow regime, respectively. The experiments showed that fluvial erosion had the greatest effect on the occurrence of cantilever failure instability because such erosion increased the width of an overhanging block but decreased its stability. This process was captured using side view video cameras and the varied acceleration signal in the $x$-direction as shown in Fig. 4(b). That was because fluvial erosion is related to loosening of weak bonds between the material particles. The observations from the present experiments were similar to those of previous studies $^{3), 8)}$. Tension cracks then developed on the 
upper surface of the cohesive banks. Such tension cracks seemed to develop only when the cantilever was already close to failure. After that, the cantilever failure occurred along the tension crack line. The dominant failure mechanism was observed to be beam-type failure clarified using the acceleration signal in the $y$-direction as shown in Fig. 4(c). This was consistent with the findings of previous researchers, who have suggested that the beam-type failure may be prevalent ${ }^{3), 7), 8)}$.

For the experimental results, the rate of fluvial erosion in Case $1(S C=30 \%)$ was greater than that in Case $2(S C=20 \%)$ under similar hydraulic conditions, as shown by the accumulated bank failure width in Fig. 5. The fluvial erosion rates at the equilibrium stages of Case 1 and 2 were 0.0025 $\mathrm{cm} / \mathrm{s}$ and $0.0014 \mathrm{~cm} / \mathrm{s}$, respectively. The main reason is that the banks with lower cohesive force are more susceptible to failure than those with higher cohesive force. Additionally, the silt-clay content could be expected to have some bearing on the susceptibility of the cohesive banks to the subaerial erosion process, as the cohesive materials with a lower cohesive force (higher silt-clay content) have greater plasticity (and hence a capacity for swelling and shrinkage $)^{8), 10), 12)}$.

The experiments were able to randomly reproduce cantilever failures - as illustrated in Fig. 3(c) - and the experimental results showed a backward erosion process in Case 2 (high cohesive force), which was similar to previous observations ${ }^{8), 13)}$. In the present study, riverbank particles were detached from the downstream region through the effect of a second wooden panel by the generation of a reverse flow. For that reason, this study considered only the center region and used streamwise-averaged data of cohesive banks to reduce the effect of the wooden panel.

The slump block formation and decomposition were the new phenomena observed in the present experiments. The slump block seemed very complex, and its dependability was very important to the cantilever failure process at the experimental scale. In the present study, the effect and role of the slump block on cantilever failure were observed and described for the first time at the experimental scale. Moreover, the effect of slump blocks on the bed channel in front of the bank, where they formed a sediment buffer that reinforced the bank and reduced fluvial erosion, was observed. Fig. 3(b) shows the slump blocks in the red rectangular block of Case 2. The average slump block dimensions in width, length and height for two different cohesive forces are presented in Fig. 6, which shows a decreasing trend for the width and length of the slump blocks in the case of the higher cohesive force. Therefore, the geometries of the slump block including its failure and decomposition mainly depended on the cohesive force of the cohesive banks. A reduction of the cohesive force not only increased the fluvial erosion rate but also affected the dimensions of the slump blocks and their decomposition rates (see Fig. 6 and 7). The observation phenomena from the present work were consistent with previous studies in terms of changing cohesive force (silt-clay content $)^{10), 11)}$. Fig. 7 shows the relationship between the volumes of slump blocks and their decomposition times in the present study. The relation seems to be almost random, without any identifiable rules governing this phenomenon. This random relationship between the volumes of slump blocks and their decomposition times has been reported in previous observations ${ }^{10)}$.

Additionally, the armoring effect of the slump block was revealed in the experimental results. The detachment from the slump and re-suspension of the materials sank and deposited in the submerged failure materials on the bed channel in front of the bank, which is shown as a brown layer at the top of failure materials (see Fig. 8). Therefore, this mechanism increased the strength of the bank-toe.

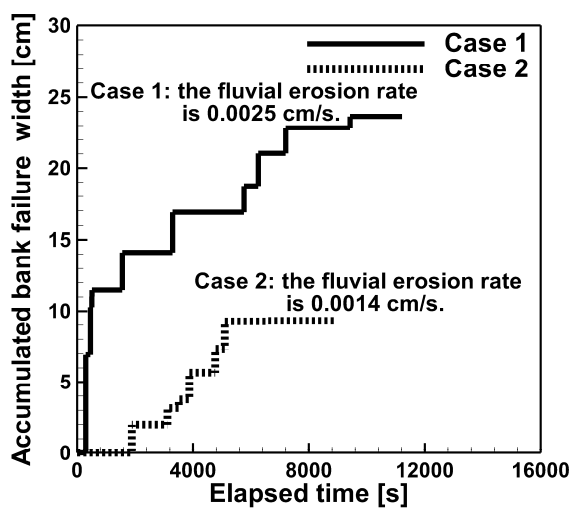

Fig.5 The comparison results of fluvial erosion rate in the experimental studies with the different silt-clay contents.

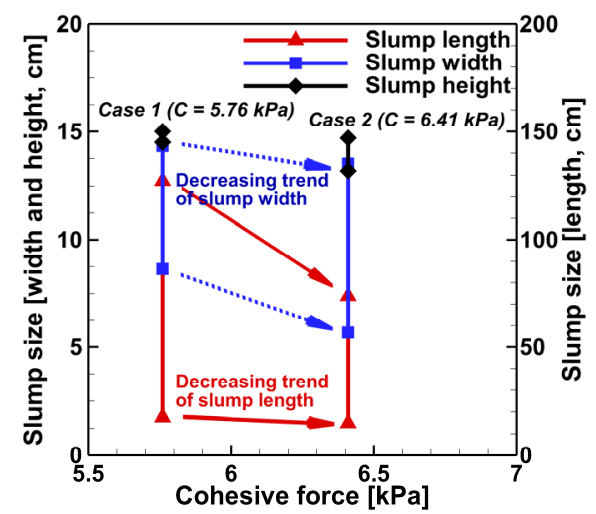

Fig.6 Variation of slump block dimensions with the different cohesive forces (Red and blue lines show a decreasing trend for the length and width of the slump blocks, respectively). 


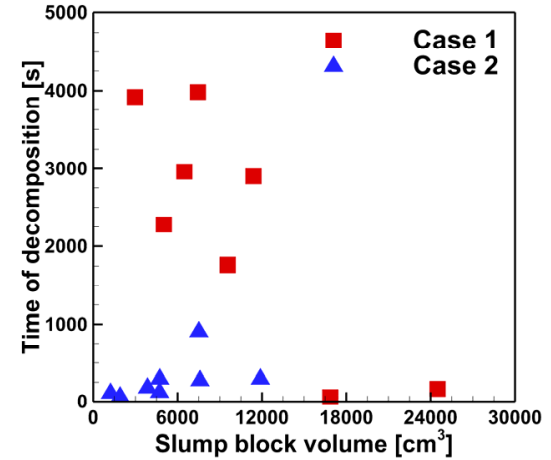

Fig.7 Slump decomposition of the various volumes with the different cohesive forces.

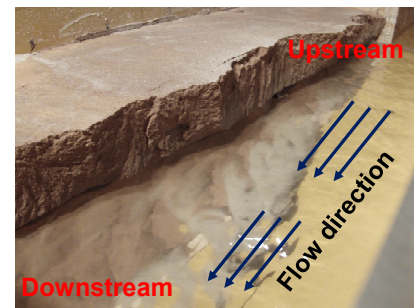

(a) The armoring effect during experimental run.

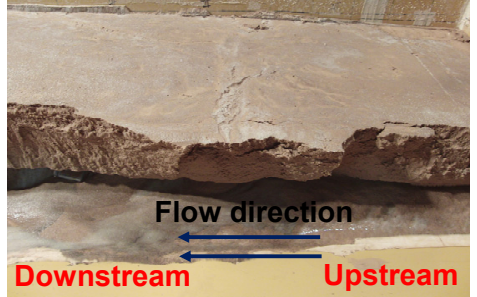

(b) The armoring effect after the equilibrium stage.

Fig.8 The armoring effect of the experimental results (Case 2).

\section{CONCLUSIONS}

This study elucidated the complex mechanisms of cantilever failure with consideration given to the slump block by means of experiments. Two types of cohesive materials with different percentages of silt-clay content were investigated under similar hydraulic conditions using acceleration sensors to clarify the cantilever failure processes. The main conclusions are as follows.

For the mechanism of cantilever failure, the experimental results showed that the fluvial erosion at the lower part generated an overhanging block in the upper part of the cohesive banks. Tension cracks then developed on the upper surface of the cohesive banks. After that, the cantilever failure occurred along the tension crack line. The dominant failure mechanism was observed to be beam-type failure.

The slump block failure and decomposition phenomena are discussed for the first time with the cantilever failure experiments on channel flow. Slump blocks were observed on the bed channel in front of the bank, where they formed a sediment buffer that reinforced banks and reduced fluvial erosion. The slump block phenomena for the formation and deformation showed a significant effect on the cohesive force of the banks and affected the bank geometry. Therefore, a reduction of the silt-clay content leads to smaller slump block dimensions as well as faster decomposition.

ACKNOWLEDGMENT: The authors would like to express their sincere thanks to the Japanese Government Scholarships for financial support.

\section{REFERENCES}

1) Taghavi, M., Dovoudi, M.H., Amiri-Tokaldany, E., and Darby, S.E.: An analytical method to estimate failure plane angle and tension crack depth for use in riverbank stability analyses, Geomorphology, Vol.123(1-2), pp.74-83, 2010.

2) Nardi, L., Rinaldi, M. and Solari, L.: An experimental investigation on mass failures occurring in a riverbank composed of sandy gravel, Geomorphology, Vol.163-164(Special issue), pp.56-69, 2012.

3) Thorne, C.R. and Tovey, N.K.: Stability of composite river banks, Earth Surf. Proc. Land., Vol.6(5), pp.469-484, 1981.

4) Abam, T.K.S.: Genesis of channel bank overhangs in the Niger Delta and analysis of mechanisms of failure, Geomorphology, Vol.18(2), pp. 151-164, 1997.

5) Fukuoka, S., Watanabe, A., Katayama, T. et al.: Erosion expansion mechanism of cohesive (silt) bank by the stream flow, Annual Journal of Hydraulic Engineering, JSCE, Vol.43, pp.695-700, 1999. (in Japanese)

6) Bahar, S.M.H. and Fukuoka, S.: Study of cohesive riverbank erosion mechanism through analysis of flow fields near and inside eroded bank, Annual Journal of Hydraulic Engineering, JSCE, Vol.46, pp.749-754, 2002.

7) Samadi, A., Amiri-Tokaldany, E., Davoudi, M.H. and Darby S.E.: Experimental and numerical investigation of the stability of overhanging riverbanks, Geomorphology, Vol.184, pp.1-19, 2013.

8) Patsinghasanee, S., Kimura, I., and Shimizu, Y.: Experimental and numerical study on overhanging failure of river bank, Annual Journal of Hydraulic Engineering, JSCE, Vol.71, No.4, pp. I_127-I_132, 2015.

9) Dulal, K.P., Kobayashi, K., Shimizu, Y., and Parker, G.: Numerical computation of free meandering channels with the application of slump blocks on the outer bends, $J$. Hydro-environ. Res., Vol.3(4), pp.239-246, 2010.

10) Dulal, K.P. and Shimizu, Y.: Experimental simulation of meandering in clay mixed sediments, J. Hydro-environ. Res., Vol.4(4), pp.329-343, 2010.

11) Parker, G., Shimizu, Y., Wilkerson, G.V., et al.: A new framework for modeling the migration of meandering rivers, Earth Surf. Proc. Land., Vol.36(1), pp.70-86, 2011.

12) Julian, J.P. and Torres, R.: Hydraulic erosion of cohesive riverbanks, Geomorphology, Vol.76(1-2), pp.193-206, 2006.

13) Hooke, J.M.: Magnitude and distribution of rates of river bank erosion, Earth Surf. Proc. Land., Vol.5(2). pp.143-157, 1980.

(Received September 30, 2015) 